\title{
Alfalfa Coumestrol Content in Response to Development Stage, Fungi, Aphids, and Cultivar
}

\author{
Rachel L. Fields,* Graham K. Barrell, Alan Gash, Jenny Zhao, Derrick J. Moot
}

\section{ABSTRACT}

Coumestrol produced by alfalfa (Medicago sativa L.) can reduce the ovulation rate of ewes. This study isolated agronomic factors that affect coumestrol levels in alfalfa. Fungal diseases explained most differences in coumestrol. Alfalfa inoculated with Stemphylium vesicarium contained $169 \pm 25.1 \mathrm{mg} \mathrm{kg}^{-1} \mathrm{dry}$ matter (DM) compared with $3.4 \pm 0.84 \mathrm{mg} \mathrm{kg}^{-1} \mathrm{DM}$ in controls. However, in field-grown alfalfa there was a low relation$\operatorname{ship}\left(R^{2}=0.388\right)$ between coumestrol content and visual fungal damage score which indicates a need for alternative methods of prediction. In the field, a range of cultivars all reached coumestrol levels reported to pose a risk to ewe reproductive performance (>25 mg kg$\left.{ }^{-1} \mathrm{DM}\right)$. In $S$. vesicarium-inoculated leaves, the modern cultivar 'Stamina 5 ' had $396 \pm 82.4 \mathrm{mg} \mathrm{kg}^{-1} \mathrm{DM}$ compared with the 40-yr-old industry standard 'Wairau' at 143 $\pm 35.6 \mathrm{mg} \mathrm{kg}^{-1} \mathrm{DM}$. Flowering in isolation did not produce a coumestrol response, with increases detected or not detected simultaneously in vegetative and flowering plants. Pea aphids had a minor effect on coumestrol content. When alfalfa was subjected to $\sim 5$ aphids per stem for 4 wk coumestrol increased from $2.4 \pm 0.39$ to $5.3 \pm 0.65 \mathrm{mg} \mathrm{kg}^{-1} \mathrm{DM}$. This study highlights fungal pathogens traditionally not considered problematic in alfalfa stands due to limited effects on stand persistence and yield, as important causal agents of elevated coumestrol levels. Plant breeding to reduce their impact is recommended.

\section{Core Ideas}

- Alfalfa cultivars still produce coumestrol contents detrimental to ewe reproduction.

- Coumestrol increased simultaneously across alfalfa of different development stages.

- Coumestrol related to fungal symptoms but prediction from symptoms was inaccurate.

- Coumestrol did not respond to pea aphids as severely as previously reported.
A LFALFA (MEDICAGO sativa L.), or lucerne, is a highquality forage legume. A potential impediment to its adoption in livestock systems is the phyto-estrogen coumestrol. Coumestrol is a potent coumestan that can decrease the ovulation rate of grazing ewes (Coop, 1977; Ramòn et al., 1993; Scales et al., 1977; Smith et al., 1979). This leads to a reduction in multiple births and an overall lower lambing rate. Most research has been conducted on the effect of coumestrol on sheep. However, as detailed in a review by Reed (2016), a few studies have also reported impaired fertility in cattle.

The effect of coumestrol on ewe ovulation rate is temporary and animals fully recover on removal from the alfalfa (Coop, 1977; Fields et al., in press). However, avoiding grazing high quality alfalfa before and during mating may reduce potential benefits of increased ovulation gained from increased ewe liveweight (Rattray et al., 1980; Thompson et al., 1990). This is particularly relevant in dry summer and/or fall periods when alfalfa may be the only feed available leading up to mating (Brown et al., 2005; King et al., 2010). Therefore identifying when and why coumestrol levels are elevated is a key requirement to refine alfalfa grazing management.

Coumestrol content within alfalfa herbage is highly variable and ranges from less than $1 \mathrm{mg} \mathrm{kg}^{-1} \mathrm{DM}$ to $600 \mathrm{mg} \mathrm{kg}^{-1}$ DM in diseased foliage (Hanson et al., 1965; Saba et al., 1972). Coumestrol contents as low as $25 \mathrm{mg} \mathrm{kg}^{-1} \mathrm{DM}$ have been demonstrated to affect ewe reproductive performance (Fields et al., in press; Ramòn et al., 1993; Smith et al., 1979). Coumestrol is a relatively stable compound and can be present in hay, silage, and pellets (Galey et al., 1993; Moravcová et al., 2004; Smith et al., 1979).

Alfalfa also contains the coumestan 4-methoxy coumestrol which is metabolized to coumestrol, however quantification of this compound is limited by unavailability of analytical standards. The other main estrogenic compounds produced by alfalfa are the isoflavones biochanin and genistein which are metabolized in the rumen to the non-estrogenic compound 4-ethylphenol (Batterham et al., 1965; Cox and Braden, 1974). This means that their levels in forage are relatively unimportant compared with coumestrol.

Factors such as fungal disease, cultivar, developmental stage, and aphid infestation have all been reported to affect coumestrol

Faculty of Agriculture and Life Sciences, Lincoln Univ., Lincoln 7647, New Zealand. Received 14 Sept. 2017. Accepted 7 Feb. 2018. *Corresponding author (Rachel.Fields@lincolnuni.ac.nz).

Abbreviations: DM, dry matter; ITS, internal transcribed spacer.
Published in Agron. J. 110:910-921 (2018)

doi:10.2134/agronj2017.09.0535

Copyright (C) 2018 by the American Society of Agronomy 5585 Guilford Road, Madison, WI 53711 USA

This is an open access article distributed under the CC BY-NC-ND license (http://creativecommons.org/licenses/by-nc-nd/4.0/)
Aonomy Journal 
content. Fungal disease is considered the main factor that elevates coumestrol content and all fungal pathogens tested to date have increased coumestrol (Bickoff et al., 1967; Hanson et al., 1965; Saba et al., 1972; Sherwood et al., 1970). Species commonly present in the field that have been tested include spring black stem (Phoma medicaginis Malbr. \& Roum), common leaf spot [Pseudopeziza medicaginis (Lib.) Sacc.], lepto or pepper leafspot [Leptosphaerulina trifolii (Rostovzev) Petr. (1959)], and anthracnose [Colletotrichum trifolii Bain, (1906)]. Fungicide applications of mancozeb or mancozeb and benomyl every 7 to $10 \mathrm{~d}$ could limit coumestrol accumulation (Hanson et al., 1965; Purves et al., 1981). However, this application frequency is unlikely to be economic for most sheep grazing systems and benomyl is no longer registered in many countries.

Aphid herbivory has also caused increased coumestrol levels in alfalfa (Kain and Biggs, 1980; Loper, 1968). However, it is unclear whether this was a direct response to the aphids or due to subsequent fungal infection at the sites of aphid damage.

Coumestrol has no demonstrated fungicidal or insecticidal properties (Loper, 1968; Sherwood et al., 1970) and studies have shown that alfalfa cultivars with resistance to fungal pathogens or aphids produced less coumestrol than susceptible cultivars (Bickoff et al., 1967; Loper, 1968; Purves et al., 1981). It was therefore hypothesized that modern cultivars may produce less coumestrol than older ones such as the 40-yr-old industry standard 'Wairau', which is aphid (Farrell and Stufkens, 1981; Kain and Biggs, 1980) and disease (Hawthorne, 1983) susceptible.

Developmental stage may also affect coumestrol content (Bickoff et al., 1960; Hanson et al., 1965). Typically, higher coumestrol was detected at flowering and seed set stages than at vegetative stages (Bickoff et al., 1960; Hanson et al., 1965; Seguin et al., 2004). This could be a problem in fall when farmers are recommended to avoid the harvest or grazing of alfalfa to give the crop time to recharge its root reserves (Moot et al., 2003). This period coincides with the start of the ewe mating season which creates contradictory management between plant and animal priorities. However, the studies that suggested a relationship between developmental stage and coumestrol content did not simultaneously compare stands at different developmental stages. They followed homogenous crops throughout the growing season. Simultaneous comparison of stands at different regrowth ages and phenological stages is used in this study to isolate how they affect coumestrol content.

Little to no coumestrol response has been reported due to alfalfa mosaic virus, stem nematode [Ditylenchus dipsaci (Kuhn)], or pathogenic bacterial [Xanthomonas alfalfae (Riker et al., 1935) Schaad et al., 2007)] infection (Hanson et al., 1965; Sherwood et al., 1970), or due to water stress (Fields et al., 2017).

This study aimed to assess potential causes of elevated coumestrol in alfalfa. This required isolation of agronomic factors to assess their individual effects on coumestrol content. Factors tested were cutting frequency and development stage (Experiment 1), cultivar (Experiment 2), fungal damage (Experiment 3), and aphids (Experiment 4). Experiments for cutting frequency, development stage, and cultivar were in the field. The aphid and fungal disease experiments were in a greenhouse. Field alfalfa was also monitored for disease severity.

\section{MATERIALS AND METHODS}

\section{Field Experiments}

\section{Experiment I: Development Stage}

Experiments la and $1 \mathrm{~b}$ compared the response of coumestrol over time in alfalfa crops that had been subjected to different cutting frequencies.

The development stage Experiments ( $1 \mathrm{a}$ and $1 \mathrm{~b}$ ) were located at Lincoln University, Canterbury, New Zealand (43⒊ ${ }^{\prime}$ 53.29" S, $172^{\circ} 27^{\prime} 54.92^{\prime \prime} \mathrm{E} ; 11 \mathrm{~m}$ above sea level) on flat land in Iversen Field [I12]. The Wakanui silt loam soil is an imperfectly drained Aquic Haplustept (USDA, 1999) formed from greywackederived loess and fluvial sediments, with $0.3 \mathrm{~m}$ of topsoil overlaying a silt to loamy sand horizon of 2- to 3-m depth (Cox, 1978). The paddock had a history of alfalfa from 2004 to 2007, forage turnip (Brassica rapa L.) in 2008 and annual ryegrass (Lolium multiflorum Lam.) from 2009 to 2010.

Paddock preparation involved it being plowed, harrowed, and rolled in September 2010 (austral spring). After plowing, $250 \mathrm{~kg} \mathrm{ha}^{-1}$ of fertilizer Sulfur Super $20(0-8-0-20$ $[\mathrm{N}-\mathrm{P}-\mathrm{K}-\mathrm{S}]$ ) and $0.8 \mathrm{~kg} \mathrm{ha}^{-1}$ trifluralin herbicide were applied, and incorporated with secondary cultivation. Alfalfa seed ('Stamina 5') was sown in November 2010 at $16 \mathrm{~kg} \mathrm{ha}^{-1}$

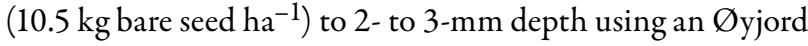
cone seeder (West Melton Engineering, West Melton, New Zealand). Seed was coated with Superstrike Lucerne (PGG Wrightson Seeds, New Zealand) which contained rhizobia, Mefenoxam fungicide for Pythium, molybdenum, and lime. Herbage was cut for hay or grazed by sheep as needed, and grass and broadleaf weeds were controlled each winter with $0.15 \mathrm{~kg} \mathrm{ha}^{-1}$ haloxyfop-P-methyl and $0.04 \mathrm{~kg} \mathrm{ha}^{-1} \mathrm{flu}-$ metsulam. Experimental plots were $2 \mathrm{~m}$ by $4 \mathrm{~m}$, and alfalfa regrowth was removed in Experiments $1 \mathrm{a}$ and $1 \mathrm{~b}$ by mowing to $65 \mathrm{~mm}$.

Experiment 1a took place in austral fall 2014. The experimental design is summarized in Table 1 and consisted of five cutting frequencies, six sampling dates, and three blocks. The blocks were located across the width of the field to account for variability due to irrigation at a neighboring site. Each of the three blocks contained five plots which were randomly allocated to the five cutting-frequency treatments. Alfalfa regrowth was 2 wk old at the onset of the experiment on 24 Mar. 2014. Every $2 \mathrm{wk}$, beginning at the experimental onset and ending 2 June 2014, the above-crown alfalfa herbage was sampled for coumestrol using a $0.2 \mathrm{~m}^{2}$ quadrat per plot. Random placements of the quadrats were pre-determined for each plot to avoid re-cutting a previously sampled area.

Experiment $1 \mathrm{~b}$ took place between 22 Oct. 2014 (austral spring) and 25 May 2015 (austral fall). Alfalfa plots were located in a different section of the field to those used for Experiment 1a. The experimental design is summarized in Table 1 and consisted of three cutting frequencies (approximately 4, 6, and $12 \mathrm{wk}$ intervals), 10 sampling dates, and three blocks. Each block contained three plots which were randomly allocated the three cutting frequency treatments. Alfalfa herbage was sampled at 2-wk intervals between 14 Jan. 2015 (austral summer) and 25 May 2015.

Rainfall data were recorded at Broadfield Meteorological Station, Lincoln, $2.5 \mathrm{~km}$ from the field site, for the duration of 
Table I. Experimental design of the field experiments used to test the response of coumestrol to development stage and cutting frequency (Experiments Ia and Ib) and to compare coumestrol levels in a range of modern cultivars (Experiments $2 \mathrm{a}$ and $2 \mathrm{~b}$ ).

\begin{tabular}{|c|c|c|c|c|c|c|c|}
\hline Locale & Independent variable A & Independent variable B & Blocks & Design & Onset & End & Stand age at onset \\
\hline \multicolumn{8}{|c|}{ Experiment Ia } \\
\hline 112 & $\begin{array}{c}\text { Cutting freq.: } \\
2,4,6,8,12 \text { wk intervals }\end{array}$ & $\begin{array}{c}\text { Time: } \\
\text { Sampled at 2-wk intervals } \\
\text { (six dates) }\end{array}$ & 3 & Split plot & 24 Mar. 2014 & 42 June 2014 & $3 \mathrm{yr}$ \\
\hline \multicolumn{8}{|c|}{ Experiment $\mathrm{Ib}$} \\
\hline 112 & $\begin{array}{l}\text { Cutting freq.: } \\
4,6,12 \text { wk intervals }\end{array}$ & $\begin{array}{c}\text { Time: } \\
\text { Sampled at 2-wk intervals } \\
\text { from 14 Jan. } 2015 \text { ( } 10 \text { dates) }\end{array}$ & 3 & Split plot & $\begin{array}{l}22 \text { Oct. } \\
2014\end{array}$ & 25 May 2015 & $4 \mathrm{yr}$ \\
\hline \multicolumn{8}{|c|}{ Experiment $2 \mathrm{a}$} \\
\hline $\mathrm{H} 7$ & 5 cultivars & $\begin{array}{c}\text { Time: } \\
\text { Sampled on five dates }\end{array}$ & 3 & Split plot & 15 Jan. 2015 & 17 May 2015 & $6 \mathrm{yr}$ \\
\hline \multicolumn{8}{|c|}{ Experiment $2 b$} \\
\hline HRA9 & 10 cultivars & $\begin{array}{c}\text { Time: } \\
\text { Sampled twice in 2016, } \\
\text { twice in } 2017\end{array}$ & $\begin{array}{l}2 \text { reps }(2016) \\
4 \text { reps }(2017)\end{array}$ & $\begin{array}{l}\text { Unbalanced } \\
\text { split plot }\end{array}$ & 7 Mar. 2016 & 19 May 2017 & $6 \mathrm{mo}$ \\
\hline
\end{tabular}

Table 2. Long-term mean rainfall $(\mathrm{mm})$ measured at Broadfield meteorological station from 1960 to 2015 and rainfall (mm) recorded at Broadfield or Burnham Sewage Plant meteorological stations for Experiments Ia and Ib (Field II2), Experiment 2a (Field H7), and Experiment 2b (Field HRA9).

\begin{tabular}{|c|c|c|c|c|c|c|}
\hline \multirow[b]{2}{*}{ Month } & \multirow[b]{2}{*}{ Long-term } & \multirow{2}{*}{$\begin{array}{c}2013-2014 \\
112\end{array}$} & \multicolumn{2}{|c|}{$2014-2015$} & \multirow{2}{*}{$\begin{array}{c}2015-2016 \\
\text { HRA9 }\end{array}$} & \multirow{2}{*}{$\begin{array}{c}2016-2017 \\
\text { HRA9 }\end{array}$} \\
\hline & & & 112 & $\mathrm{H} 7$ & & \\
\hline \multicolumn{7}{|l|}{ Winter } \\
\hline June & 61.8 & 209 & 45.2 & 56.6 & 75.8 & 50.4 \\
\hline July & 61.7 & 30.0 & 49.0 & 31.9 & 37.2 & 15.2 \\
\hline Aug. & 62.1 & 41.0 & 15.2 & 16.3 & 31.2 & 38.2 \\
\hline \multicolumn{7}{|l|}{ Spring } \\
\hline Sept. & 39.8 & 30.6 & 24.6 & 25.0 & 55.8 & 25.2 \\
\hline Oct. & 47.2 & 69.8 & 18.2 & 26.1 & 8.8 & 55.4 \\
\hline Nov. & 50.2 & 45.8 & 44.6 & 35.1 & 13.2 & 29.6 \\
\hline \multicolumn{7}{|c|}{ Summer } \\
\hline Dec. & 52.6 & 64.2 & 25.6 & 30.6 & 56.8 & 48.6 \\
\hline Jan. & 48.2 & 12.2 & 10.0 & 17.4 & 91.2 & 42.0 \\
\hline Feb. & 42.4 & 39.2 & 19.2 & 18.6 & 24.2 & 2.6 \\
\hline \multicolumn{7}{|l|}{ Fall } \\
\hline Mar. & 52.9 & 136 & 40.4 & 46.7 & 33.8 & 73.3 \\
\hline Apr. & 55.5 & 161 & 77.6 & 106 & 9.6 & III \\
\hline May & 56.8 & 44.6 & 6.4 & 8.8 & 80.4 & 48.4 \\
\hline Annual & 631 & 883 & 376 & 420 & 518 & 540 \\
\hline
\end{tabular}

Experiments la and $1 \mathrm{~b}$. These rainfall and long-term (19602015) data are provided in Table 2. In Experiment 1a, rainfall was $136 \mathrm{~mm}$ for Mar. 2014 and $161 \mathrm{~mm}$ for April 2014 (longterm means are 52.9 and $55.5 \mathrm{~mm}$, respectively) while rainfall in May 2014 was $44.6 \mathrm{~mm}$ (long-term mean of $56.8 \mathrm{~mm}$ ). Rainfall prior to the experiment was $12.2 \mathrm{~mm}$ in January and $39.2 \mathrm{~mm}$ in February (long-term means are 48.2 and $42.4 \mathrm{~mm}$, respectively). For Experiment 1b, rainfall from December 2014 through February 2015 and for May 2015 was less than half of the longterm mean. Rainfall in Mar. 2015 was also below average while rainfall in April 2015 was above average.

\section{Experiment 2: Cultivar}

Experiments $2 \mathrm{a}$ and $2 \mathrm{~b}$ compared coumestrol contents of 5 then 10 field-grown alfalfa cultivars, respectively.

Experiment 2a tested 'Grasslands Kaituna', 'Stamina 5', 'Stamina 6GT', 'Rhino', and 'Runner' on flat land in Field
$\mathrm{H} 7$ of the Homestead Block, Ashley Dene Farm, Springston, Canterbury, New Zealand (4339'24" S, 172 $\left.19^{\circ} 32^{\prime \prime} \mathrm{E}\right)$ in autumn 2015. The Lowcliffe moderately deep and Lowcliffe stony silt loams (Hewitt, 2010; Webb and Bennett, 1986) of Field H7 are Aquic Haplustalfs (USDA, 1999). In September 2008 the paddock was plowed, harrowed, and rolled. After plowing, $2 \mathrm{t} \mathrm{ha}^{-1}$ lime and $125 \mathrm{~kg} \mathrm{ha}^{-1}$ fertilizer Sulfur Super 15 (0-9-0-15 [N-P-K-S]) fertilizer were applied. Alfalfa seed $\left(10 \mathrm{~kg}\right.$ bare seed ha $\left.{ }^{-1}\right)$ was sown in November 2008 with an $\varnothing$ yjord cone seeder in plots of $6.3 \mathrm{~m}$ by $24.5 \mathrm{~m}$. Herbage was cut for hay or grazed by sheep as needed.

The experimental design is summarized in Table 1 . The three blocks were in separate subsections of Field $\mathrm{H} 7$ that had been rotationally grazed between sowing and the spring prior to the experiment. Alfalfa herbage was sampled three times between 15 Jan. 2015 and 5 Mar. 2015. The paddock was grazed for approximately 2 wk from 17 Mar. 2015 and the re-growth sampled on 
2 and 17 May 2015. Rainfall data (Table 2) for Experiment 2a were recorded at Burnham Sewage Plant Meteorological Station, Burnham, located $4 \mathrm{~km}$ from the field site. Rainfall in January, February and May 2015 was less than half of the long-term mean. Rainfall in December 2014 was also below average while rainfall in Mar. 2015 was near average and April 2015 was above average.

For Experiment 2b, ten cultivars ('54V09', '55Q27', 'Force 4', 'Force 7', 'Force 11', 'Grasslands Kaituna', 'Takahe', 'Torlesse', 'SFR27-018', and 'Venus') were sown with a Flexiseeder drill (Flexiseeder Ltd., New Zealand) at $10 \mathrm{~kg}$ bare seed ha ${ }^{-1}$ on flat land in Field HRA9 of the Horticultural Research Area, Lincoln University, in November 2015. The plots were $2.1 \mathrm{~m}$ by $14 \mathrm{~m}$ with $2.5-\mathrm{m}$ gaps between blocks. Following establishment, plots were sprayed with flumetsulum $\left(0.04 \mathrm{~kg} \mathrm{ha}^{-1}\right)$ herbicide in early December 2015 and with $0.13 \mathrm{~kg} \mathrm{ha}^{-1}$ pirimicarb insecticide 1 wk later. Plots were sprayed with $0.75 \mathrm{~kg} \mathrm{ha}^{-1}$ simazine and $0.15 \mathrm{~kg} \mathrm{ha}^{-1}$ haloxyfop-P-methyl herbicides in July and August 2016, respectively. The paddock had a history of kale (Brassica oleracea L.) in 2012 and Lolium perenne L. with Trifolium repens L. from November 2013 until September 2015. As for Experiment 1, the Wakanui silt loam in Field HRA9 is an imperfectly drained Aquic Haplustept (USDA, 1999).

The experimental design is summarized in Table 1. Alfalfa herbage was sampled from two blocks on 7 Mar. 2016 and 20 Apr. 2016, and from four blocks on 19 Mar. 2017 and 19 May 2017. Rainfall data for Field HRA9 (Table 2) were recorded at Broadfield Meteorological Station, located $2.8 \mathrm{~km}$ from the field site. Rainfall was above average in January and May 2016, and below average from February to April 2016. Rainfall was $2.6 \mathrm{~mm}$ for Field HRA9 (long-term mean of $42.4 \mathrm{~mm}$ ) in February 2017, above average in March and April 2017 and near average in May 2017.

\section{Greenhouse Experiments}

Potting mix used for the greenhouse experiments (Experiments 3 and 4 ) consisted of $80 \%$ composted bark and $20 \%$ pumice grade 1 to $7 \mathrm{~mm}$. The potting mix was mixed with $3 \mathrm{~g}$ per liter of Everris Osmocote Exact 3- to 4-mo patterned release fertilizer (16-3.9-10 [N-P-K]), $1 \mathrm{~g} \mathrm{~L}^{-1}$ horticultural lime (Southern Horticultural Products Ltd, New Zealand), and $1 \mathrm{~g} \mathrm{~L}^{-1}$ of Hydraflo Wetting Agent. Seeds were planted at a rate of ten seeds per pot and thinned to three plants per pot.

Pots were inoculated with rhizobia [Sinorhizobium meliloti (Dangeard 1926) De Lajudie et al. 1994], using methodology adapted from Vincent (1970). Plants were grown in blocks to account for variability within the greenhouse.

\section{Experiment 3: Fungal Disease}

Experiment 3 tested whether greenhouse-grown alfalfa infected with Stemphylium vesicarium had elevated coumestrol levels relative to control alfalfa. This disease was tested due to incidences of low coumestrol content despite the presence of Stemphylium leaf spot symptoms in Experiment 1a. The experimental design of Experiment 3 is summarized in Table 3.

To isolate Stemphylium spp., symptomatic alfalfa leaf and stem pieces ( $<5 \mathrm{~mm}$ diameter) were collected from Field I12 in January 2017, surface sterilized in 70\% ethanol for 30, 60, 90 or $120 \mathrm{~s}$, and placed on V8 agar. The V8 agar was prepared as described by Tuite (1969). To decrease bacterial contamination antibiotics were added to the V8 agar of the plates used to establish primary cultures. The antibiotics were ampicillin (Sigma Aldrich, Missouri) at a rate of $0.1 \mathrm{~g} \mathrm{~L}^{-1}$ and/or penicillin-streptomycin (Sigma Aldrich, Missouri) at a rate of 80 units penicillin and $0.08 \mathrm{mg}$ streptomycin per milliliter. Concentrations were based on manufacturer recommendations. Agar was then poured into $86.5-\mathrm{mm}$ wide, $14.5-\mathrm{mm}$ tall Petri dishes.

Agar plates were incubated at $25^{\circ} \mathrm{C}$ for approximately $7 \mathrm{~d}$ in the dark before sub-culturing small sections of agar onto clean plates. Sub-cultured plates were incubated and fungal species identified by spore morphology. Plates were sub-cultured until monocultures were obtained. For the final sub-culture, plates were incubated for $4 \mathrm{~d}$ in darkness and then exposed to $48 \mathrm{~h}$ of natural day and night cycles for sporulation.

Fungal DNA was extracted using the Extract-N-Amp kit (Sigma Aldrich, Missouri) as recommended by the manufacturer. Typically, a small section of mycelium was added to $100 \mathrm{~mL}$ of extraction solution and incubated at $95^{\circ} \mathrm{C}$ for 10 min. After this, $100 \mathrm{~mL}$ of dilution solution was added, the sample was vortexed, and stored at $4^{\circ} \mathrm{C}$. The ribosomal internal transcribed spacer (ITS) was amplified in Extract-N-Amp PCR ReadyMix (Sigma-Aldrich, Missouri) with ITS1 and ITS4 primers (White et al., 1990), and the b-tubulin (TUB2) region with T1 (O’Donnell and Cigelnik, 1997) and Bt2b primers (Glass and Donaldson, 1995). The reactions were performed in an Applied Biosystems ProFlex PCR system (Thermo Fisher Scientific, Massachusetts). The ITS thermal program was $3 \mathrm{~min}$ at $94^{\circ} \mathrm{C}$, followed by 40 cycles of $94^{\circ} \mathrm{C}$ for $1 \mathrm{~min}, 55^{\circ} \mathrm{C}$ for $30 \mathrm{~s}$ and $72^{\circ} \mathrm{C}$ for $1 \mathrm{~min}$ with a final stage of $7 \mathrm{~min}$ at $72^{\circ} \mathrm{C}$. The b-tubulin thermal program was $5 \mathrm{~min}$ at $95^{\circ} \mathrm{C}$, followed by 35 cycles of $95^{\circ} \mathrm{C}$ for $30 \mathrm{~s}, 52^{\circ} \mathrm{C}$ for $1 \mathrm{~min}$, and $72^{\circ} \mathrm{C}$ for $1 \mathrm{~min}$ with a final stage of $5 \mathrm{~min}$ at $72^{\circ} \mathrm{C}$. The DNA was sequenced by the Lincoln University Bio-protection Research Centre and compared with GenBank database sequences using the nucleotide BLAST algorithm (https://blast.ncbi.nlm.nih.gov/Blast.cgi).

Nucleotide BLAST of the ITS sequence and $\beta$-tubulin gene sequences showed the fungal species to most likely be Stemphylium vesicarium (Wallr.) E.G. Simmons, with 99\% sequence match. $S$. vesicarium is a cool temperature biotype of Stemphylium spp. that infects alfalfa (Irwin and Bray, 1991).

Alfalfa was sown into 18 -cm deep by $14-\mathrm{cm}$ wide, $2-\mathrm{L}$ pots (VCE 14, Pöppelmann, Germany). When plants were 1 mo old, fungal spores were suspended in distilled water containing $0.01 \%$ Tween 20 . The spore concentration was determined with a hemocytometer and then diluted to 5000 spores $\mathrm{mL}^{-1}$. From each pot, two randomly selected, fully expanded leaves per pot were punctured in six places per leaflet. Spore solution or a control solution of distilled water was then liberally applied to alfalfa leaves and stem of the entire plant by paintbrush, so that each pot received approximately $4 \mathrm{~mL}$ of solution. Plants were sealed in plastic bags for $1 \mathrm{wk}$ outdoors under shade. Temperatures ranged from 8 to $26^{\circ} \mathrm{C}$ during this period. The two leaves and whole plants were harvested 1 or $2 \mathrm{wk}$ after infection and the area of fungal damage on punctured leaflets was assessed with Leaf Doctor (Pethybridge and Nelson, 2015).

\section{Experiment 4: Aphids}

For the aphid experiments pea aphids (Acyrthosiphon pisum Harris) were initially sourced from an alfalfa stand and a 
Table 3. Experimental design of the greenhouse experiments used to test the response of coumestrol in different alfalfa cultivars to fungal disease (Experiment 3) and aphid damage (Experiments 4a and 4b).

\begin{tabular}{|c|c|c|c|c|c|c|}
\hline $\begin{array}{l}\text { Independent } \\
\text { variable A }\end{array}$ & $\begin{array}{l}\text { Independent } \\
\text { variable B }\end{array}$ & $\begin{array}{l}\text { Independent } \\
\text { variable C }\end{array}$ & Blocks & Design & $\begin{array}{l}\text { Time since } \\
\text { sowing }\end{array}$ & $\begin{array}{l}\text { Regrowth } \\
\text { length }\end{array}$ \\
\hline \multicolumn{7}{|l|}{ Experiment 3} \\
\hline S. vesicarium vs. control & $\begin{array}{c}2 \text { cultivars: } \\
\text { Wairau, Stamina } 5\end{array}$ & $\begin{array}{c}\text { Time: } \\
\text { Sampled } 7 \text { \& } 14 \mathrm{~d} \\
\text { post-infection }\end{array}$ & 3 & Split plot & One month & One month \\
\hline \multicolumn{7}{|l|}{ Experiment 4a } \\
\hline $\begin{array}{l}\text { Aphids vs. control (whole } \\
\text { plant exposed for } 4 \text { wk) }\end{array}$ & $\begin{array}{c}3 \text { cultivars:Wairau, Grasslands } \\
\text { Kaituna, Force } 4\end{array}$ & N/A & 4 & $\begin{array}{l}\text { Complete Randomized } \\
\text { Block Design }\end{array}$ & $9 \mathrm{mo}$ & 3 wk \\
\hline \multicolumn{7}{|l|}{ Experiment $4 b$} \\
\hline $\begin{array}{l}\text { Aphid vs. no aphid (two } \\
\text { leaves per plant exposed } \\
\text { for } 5 \mathrm{~d} \text { ) }\end{array}$ & $\begin{array}{l}4 \text { cultivars: } \\
\text { Wairau, Grasslands Kaituna, } \\
\text { Force 4, Torlesse }\end{array}$ & N/A & 3 & $\begin{array}{l}\text { Complete Randomized } \\
\text { Block Design }\end{array}$ & $6 \mathrm{mo}$ & 3 wk \\
\hline
\end{tabular}

population maintained on broad bean plants (Vicia faba L.) in cubical insect cages with 450-mm dimensions.

For Experiment 4a, the response of coumestrol levels to aphids was investigated on whole plants in a greenhouse. The mean maximum and minimum temperatures during this period were $27 \pm 0.6^{\circ} \mathrm{C}$ and $15 \pm 0.2^{\circ} \mathrm{C}$, respectively. For this experiment, three cultivars of alfalfa were either exposed or not exposed to pea aphids for $4 \mathrm{wk}$ in four blocks of insect rearing cages in side-by-side \pm aphid pairs, as summarized in Table 3.

The three cultivars of alfalfa used were 'Force 4', 'Wairau', and 'Grasslands Kaituna'. 'Grasslands Kaituna' is rated as resistant to pea aphid, 'Wairau' is rated susceptible (Dunbier and Easton, 1982) while a resistant rating is not published for 'Force 4'. Plants were grown for 9 mo with cutting to approximately $4-\mathrm{cm}$ height every $6 \mathrm{wk}$ before the experiment commenced. After 3 wk of re-growth, plants were put into the cages, with one pot of each cultivar per cage. To each rearing cage, $0.25 \pm 0.033 \mathrm{~g}$ of aphids or no aphids were added. Four weeks later, the number of aphids per stem was counted for each of ten randomly selected stems at harvest. Alfalfa was harvested to 30-mm height above the soil surface.

For Experiment $4 \mathrm{~b}$ the effect of a single aphid on a leaf was investigated. The average maximum and minimum temperatures during this period were $23 \pm 0.4^{\circ} \mathrm{C}$ and $13 \pm 0.7^{\circ} \mathrm{C}$, respectively. Individual leaves on different plants of four cultivars of alfalfa were either exposed, or not exposed, to pea aphids with a duplicate pair of leaves for each treatment and three blocks. The experimental design is summarized in Table 3.

The four alfalfa cultivars used were 'Torlesse' (no published pea aphid resistance rating), 'Force 4', 'Wairau', and 'Grasslands Kaituna'. Plants were grown for 6 mo prior to the experiment and managed in the same manner as for Experiment 4a. After 3 wk of re-growth, clip-cages were attached to the first fully unfolded leaf of two plants per pot, and either one or no pea aphids were added to each duplicate pair of cages. The clipcages were based on the design described by (Noble, 1958), but used acrylic tubing with an internal diameter of $20 \mathrm{~mm}$. To support the cages they were tied to a stake in the pot.

After $5 \mathrm{~d}$, the clip-cages and the aphids were removed and leaflets harvested. One leaflet per leaf was stained to measure fungal presence based on the protocol from Tuite (1969). For this, leaflets were put into a 1:1 (v/v) glacial acetic acid to $95 \%$ ethanol mix for $15 \mathrm{~min}$ until white. They were then soaked for $5 \mathrm{~min}$ in lactoglycerol cotton blue to stain cell damage and
Table 4. Damage severity score categories for fungal and insect damage (Harvey and Martin, 1980; James, 197I).

\begin{tabular}{lc}
\hline Score & Description \\
\hline$I$ & No symptoms \\
2 & Trace: I to $4 \%$ of area affected \\
3 & Light to moderate: 5 to $20 \%$ of area affected \\
4 & Heavy: 2 I to $50 \%$ of area affected \\
5 & Severe: $>50 \%$ of area affected \\
\hline
\end{tabular}

fungi. Leaflets were then rinsed with a 50:50 water/glycerol mix and mounted on a microscope slide.

\section{Alfalfa Processing}

The alfalfa samples for Experiments 1 to 4 were stored in a cooler at $4^{\circ} \mathrm{C}$ until they were processed within $48 \mathrm{~h}$. From the samples fungal pathogen species were identified and fungal damage was scored using the criteria based on Harvey and Martin (1980) and plant assessment keys from James (1971). The categories of the scoring system are outlined in Table 4.

The field samples were scored for mean development stage using the criteria and calculations given in Fick and Mueller (1989). A random sample of 25 stems was obtained and each stem was individually scored using the criteria in Table 5 and the mean stage was determined as:

$$
\text { Mean development stage }=\Sigma(n x) / \sum n
$$

where $n$ is the number of stems at each growth stage, $x$. Field and whole pot alfalfa samples were oven dried for at least $48 \mathrm{~h}$ at $60^{\circ} \mathrm{C}$ and weighed to calculate metric tons of dry matter yield per hectare ( $\mathrm{tDM} \mathrm{ha}{ }^{-1}$ ) or g DM pot ${ }^{-1}$.

\section{Measurement of Coumestrol in Alfalfa}

The dried field and whole pot alfalfa samples were ground with two machines, one that coarsely ground the material and could cut the alfalfa stems, followed by a second machine (Ultra Centrifugal Mill ZM 200, Retsch, Germany) that ground the material finely through a $1-\mathrm{mm}$ sieve. Samples of $0.5 \mathrm{~g}$ were weighed into $5 \mathrm{~mL}$ HPLC-grade $99.9 \%$ methanol (SigmaAldrich, Missouri) in $15 \mathrm{~mL}$ conical bottom tubes (Axygen Scientific, California). For individual leaf samples, the fresh leaves were placed in a $1.5-\mathrm{mL}$ microcentrifuge tube (Axygen Scientific, California) frozen with liquid nitrogen, ground to a fine powder with a polypropylene pellet pestle (Sigma-Aldrich, Missouri), and extracted with methanol at a 1:10 (w/v) ratio. All 


\begin{tabular}{lll}
\hline Stage & \multicolumn{1}{c}{ Name } & \multicolumn{1}{c}{ Definition } \\
\hline 0 & Early vegetative & Stem shorter than $15 \mathrm{~cm}$, no buds, flowers or seed pods. \\
1 & Mid vegetative & Stem length $15-30 \mathrm{~cm}$, no buds, flowers or seed pods. \\
2 & Late vegetative & Stem longer than $30 \mathrm{~cm}$, no buds, flowers or seed pods. \\
3 & Early bud & One or two nodes with buds, no flowers or seed pods. \\
4 & Late bud & Three or more nodes with buds, no flowers or seed pods. \\
5 & Early flower & One node with one open flower, no seed pods. \\
6 & Late flower & Two or more nodes with open flowers, no seed pods. \\
7 & Early seed pod & One to three nodes with green seed pods. \\
8 & Late seed pod & Four or more nodes with green seed pods. \\
9 & Ripe seed pod & Nodes with mostly brown, mature seed pods. \\
\hline
\end{tabular}

Table 6. Coumestrol content rating scale used to categorize alfalfa samples in Experiments I to 4.

\begin{tabular}{ll}
\hline Coumestrol content & \multicolumn{1}{c}{ Rating } \\
\hline \multicolumn{1}{c}{$\mathrm{mg} \mathrm{kg}^{-1} \mathrm{DM}$} & Negligible \\
$\mathrm{I}-10$ & Low \\
$10-25$ & Moderately low \\
25 & Critical threshold \\
$25-50$ & Moderate \\
$50-100$ & Moderately high \\
$100-150$ & High \\
$>150$ & Extreme \\
\hline
\end{tabular}

alfalfa samples were vortex mixed for $20 \mathrm{~s}$ and put on an endover-end mixer for $16 \mathrm{~h}$ at room temperature. They were then centrifuged at $4700 \mathrm{~g}$ for $5 \mathrm{~min}$ and $1 \mathrm{~mL}$ of supernatant was transferred to a $1.5-\mathrm{mL}$ microcentrifuge tube.

Glass fiber syringe filters $(0.7 \mu \mathrm{m}$, MicroAnalytix, New Zealand) were used to filter the supernatant into $2 \mathrm{~mL}$ glass auto-sampler vials (Thermo Fisher Scientific, Massachusetts). Extracted samples were analyzed for coumestrol content using HPLC with methodology adapted from Wang et al. (1990). The HPLC analyses were performed with an Agilent 1100 series instrument (Agilent Technologies, Waldbronn, Germany) equipped with binary pumps, and a fluorescence detector set at $365 \mathrm{~nm}$ for excitation and $418 \mathrm{~nm}$ for emission. The injection volume was $10 \mathrm{~mL}$. Separation was performed on an ACE reverse phase column $(\mathrm{C} 18,3 \mu \mathrm{m}, 150 \mathrm{~mm}$ by $4.6 \mathrm{~mm}$, Winlab, Scotland) at $25^{\circ} \mathrm{C}$, with the flow rate set at $0.5 \mathrm{~mL} \mathrm{~min}^{-1}$. Solvent A was deionized water and solvent B was $100 \%$ methanol. Elution of coumestrol was performed by linearly increasing the percentage of solvent B from 40 to $100 \%$ over $14 \mathrm{~min}$. Solvent B was maintained at $100 \%$ for $2 \mathrm{~min}$. The column was re-equilibrated for 9 min between samples. Coumestrol (Sigma-Aldrich, Missouri) was used to make a calibration curve from 0.5 to $20 \mathrm{mg} \mathrm{L}^{-1}$.

\section{Coumestrol Rating Scale}

The criteria in Table 6, on a scale from negligible to extreme, are used to describe the coumestrol level in alfalfa. A coumestrol level of $25 \mathrm{mg} \mathrm{kg}^{-1} \mathrm{DM}$ is used as a threshold above which coumestrol has been shown to reduce ewe reproductive performance (Fields et al., in press; Ramòn et al., 1993; Smith et al., 1979). However, this level should be regarded with caution. It is possible that the true safe level is below this value, but its determination was not an aim of this study.

\section{Statistical Analyses}

Statistical analyses were performed with Genstat 16.1. To reduce residual variance heterogeneity and improve normality, coumestrol data were square-root transformed for Experiment 1a and data were $\log _{10}$ transformed for Experiments $1 b, 2 b$, 3 , and $4 \mathrm{~b}$. Split-plot analysis of variance (ANOVA) was used to analyze variables in Experiments 1a, 1b, $2 \mathrm{a}$ and 3. Two-way ANOVA was used for Experiments $4 \mathrm{a}$ and $4 \mathrm{~b}$. Fisher's protected least significant difference (LSD) post hoc test was used to separate means when the ANOVA was significant $(\alpha=0.05)$. Restricted maximum likelihood (REML) analysis was used to analyze data from Field HRA9 in Experiment 2b. The LSD (5\%) were used to compare the means when the REML analysis was significant $(\alpha=0.05)$. This experiment had an unbalanced design, with two replicates in 2016 and four replicates in 2017.

Graphs for these experiments were drawn with the dependent variable kept transformed. The standard error of the mean (SEM) is presented where mean data are reported in the format: mean \pm SEM. Back-transformed means of transformed variables are given in-text. SEMs for the backtransformed means were calculated with statistical differentials (Kempthorne and Folks, 1971).

To assess coumestrol contents measured in Experiments 1 and 2 against fungal damage score a $\log _{10}$ transformation was used to normalize the coumestrol data. Linear regression was performed on the transformed data against the fungal damage score and the $95 \%$ confidence interval calculated in Minitab 16. This relationship was graphed with the dependent variable and upper and lower confidence limits back transformed.

\section{RESULTS \\ Experiment I: Cutting Frequency and Development Stage}

\section{Experiment Ia}

Alfalfa remained in a vegetative state (Stages 0 to 2 ) throughout Experiment 1a. From 7 Apr. 2014 unmown alfalfa was at Stage 2 and after cutting remained at Stage 0 . Square root transformed coumestrol was affected $(P<0.001)$ by the time $\times$ cutting frequency interaction (Fig. 1).

Pre-coumestrol spike (24 Mar. and 7 Apr. 2014). For the first $4 \mathrm{wk}$ of the experiment, coumestrol content was low to moderately low in all plots. Coumestrol was higher $(P<0.001)$ on 7 Apr. 2014 (23.0 $\left.\pm 7.30 \mathrm{mg} \mathrm{kg}^{-1} \mathrm{DM}\right)$ than on $24 \mathrm{Mar}$. $2014\left(5.8 \pm 3.66 \mathrm{mg} \mathrm{kg}^{-1} \mathrm{DM}\right)$. There were no differences $(P>0.05)$ in coumestrol content among cutting frequencies 


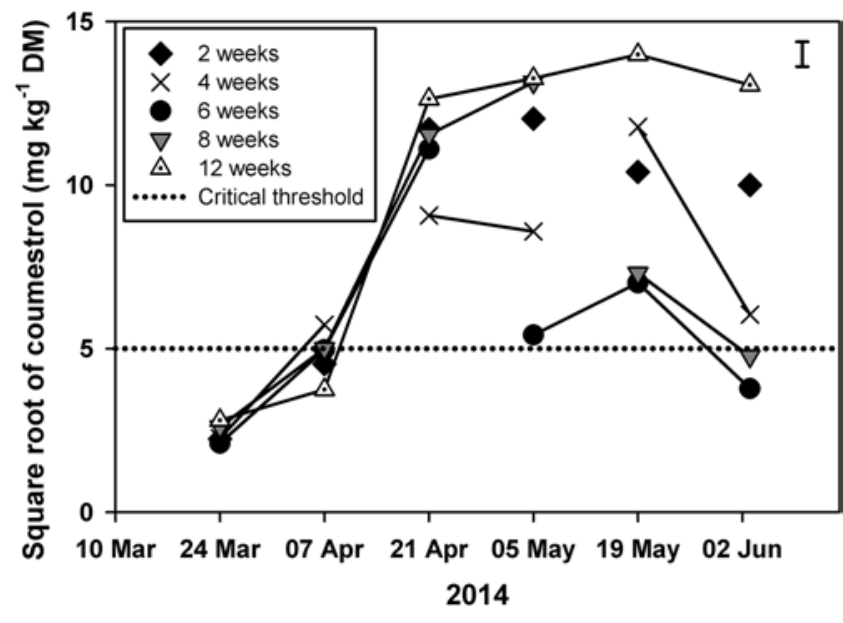

Fig. I. Square root transformed coumestrol content of alfalfa under cutting intervals of 2, 4, 6, 8, and I2 wk from 24 Mar. to 2 June 20I4. Line breaks indicate when alfalfa had been mown. Dotted line is the square root of the critical value $(25 \mathrm{mg}$ $\mathrm{kg}^{-1} \mathrm{DM}$ ) above which alfalfa is reported to be a risk for ewe reproductive performance. Error bar is the standard error of the mean for the interaction between treatment and time.

on either date. On 24 Mar. 2014 all plots contained 2-wk-old regrowth because no cutting treatments had been applied and the alfalfa was early vegetative (Stages 0 to 1 ). Plants had a fungal damage score of 4 due predominantly to cool-type Stemphylium spp. symptoms. On 7 Apr. 2014, alfalfa of the 2-wk cutting frequency plots had 2-wk regrowth and all other plots had 4-wk regrowth. Stemphylium leaf spot symptoms were still present and the fungal damage score was 2.8 .

Coumestrol spike (21 Apr. 2014). Coumestrol further increased $(P<0.001)$ on 21 Apr. 2014 across all plots. This marked elevation was designated as a 'coumestrol spike'. The 6-wk-old regrowth of the 6-, 8-, and 12-wk cutting frequency plots had a high mean coumestrol content of $138 \pm 17.9 \mathrm{mg}$ $\mathrm{kg}^{-1} \mathrm{DM}$. This was similar $(P=0.398)$ to the regrowth of the alfalfa cut every $2 \mathrm{wk}$, which had $137 \pm 17.8 \mathrm{mg} \mathrm{kg}^{-1} \mathrm{DM}$. The 2-wk regrowth of the 4-wk cutting frequency plots had a lower $(P=0.025)$ coumestrol content with a moderately high $82.3 \pm$ $13.79 \mathrm{mg} \mathrm{kg}^{-1} \mathrm{DM}$. There was no relationship between the coumestrol content of alfalfa and dry matter yield which ranged from 0.1 to $1.9 \mathrm{tDM} \mathrm{ha}^{-1}(P=0.276)$, plant height which ranged from 2 to $40 \mathrm{~cm}(P=0.238)$ or average number of leaves per stem which ranged from 2 to 17 per stem $(P=0.196)$. Alfalfa had an average fungal damage score of 3.5 , and spring black stem and leaf spot (Phoma sp.) symptoms were present on both leaves and stems in all plots in addition to Stemphylium leaf spot.

Post-coumestrolspike (21 Apr. to 2June 2014). From 21 April to 2 June 2014 coumestrol content remained elevated in the plots that had not yet been mown, with an extreme mean coumestrol content of $161 \pm 19.3 \mathrm{mg} \mathrm{kg}^{-1} \mathrm{DM}(n=21)$. These plots had average fungal damage scores of 4 on 5 May and 5 on 2 June 2014. Cutting of the unmown alfalfa resulted in lower $(P<0.001)$ coumestrol contents. For example, 2 -wk regrowth of alfalfa cut at 6- or 8-wk frequency had $29.4 \pm 8.24 \mathrm{mg} \mathrm{kg}^{-1} \mathrm{DM}$ (moderate) and $53.3 \pm 11.10 \mathrm{mg} \mathrm{kg}^{-1} \mathrm{DM}$ (moderately high), respectively.

In contrast, coumestrol content of the 2 -wk-old regrowth of alfalfa cut at 4 -wk intervals increased $(P=0.005)$ to a high level of $139 \pm 17.9 \mathrm{mg} \mathrm{kg}^{-1} \mathrm{DM}$ on 19 May 2014, compared

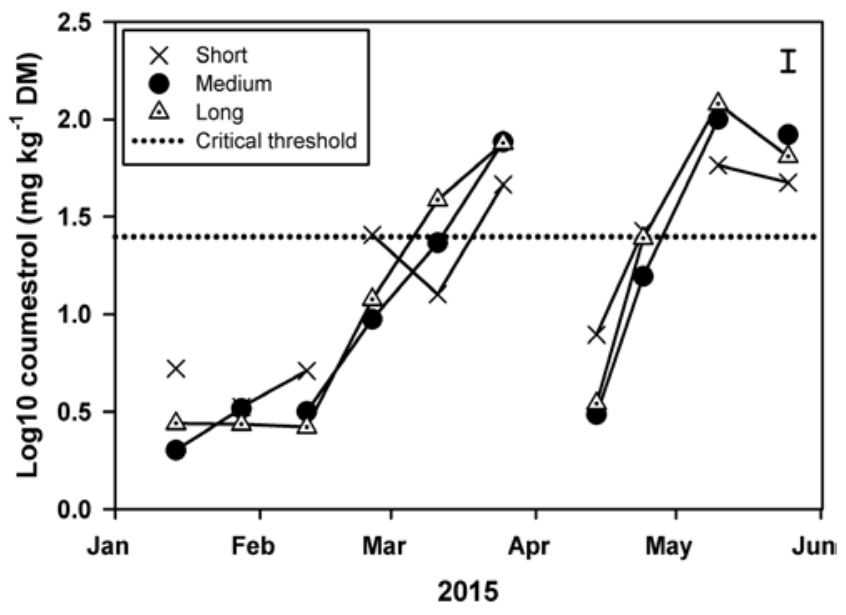

Fig. 2. Log 10 transformed coumestrol content of alfalfa under short, medium, and long cutting intervals between Jan. 2015 and May 2015. Line breaks indicate when alfalfa had been mown. Dotted horizontal line is the $\log _{10}$ of the critical value $(25 \mathrm{mg}$ $\mathrm{kg}^{-1}$ DM) above which alfalfa is reported to be a risk for ewe reproductive performance. Error bar is the standard error of the mean for the interaction between treatment and time.

with a moderately high level of $73.6 \pm 13.04 \mathrm{mg} \mathrm{kg}^{-1} \mathrm{DM}$ on 5 May 2014. It then decreased $(P<0.001)$ to a moderate 36.5 $\pm 9.18 \mathrm{mg} \mathrm{kg}^{-1} \mathrm{DM}$ in the 4 -wk-old regrowth on $2 \mathrm{June} 2014$. The coumestrol content of the alfalfa cut every $2 \mathrm{wk}$ remained elevated and did not respond $(P>0.116)$ to the subsequent cuts.

\section{Experiment Ib}

In Experiment $1 \mathrm{~b}, \log _{10}$ transformed coumestrol content of alfalfa was affected by the interaction $(P=0.001)$ between time and cutting frequency (Fig. 2).

14 Jan. to 11 Feb. 2015. By 14 Jan. 2015, all plots had received 3 mo under a short, medium or long cutting regime. During this period, the short rotation was mown three times, the medium rotation twice, and the long rotation once. On 14 January coumestrol was low, but higher $(P=0.008)$ in the short rotation plots than the medium rotation $(5.3 \pm 1.30$ vs. $2.0 \pm 0.49 \mathrm{mg}$ $\mathrm{kg}^{-1} \mathrm{DM}$, respectively). All plots were $4 \mathrm{wk}$ old and at the bud stage (Stages 3 to 4 ). On 11 Feb. 2015, coumestrol was still low at $3.5 \pm 0.86 \mathrm{mg} \mathrm{kg}^{-1} \mathrm{DM}$ with no differences $(P=0.061)$ among cutting frequencies. The short rotation alfalfa was 4 wk old (Stage 3), the medium rotation was $2 \mathrm{wk}$ old (Stage 0 ), and the long rotation alfalfa was 8 wk old (Stages 7 to 8 ).

First coumestrol spike (25 Feb. to 25 Mar. 2015). On 25 Feb. 2015, mean coumestrol had increased $(P=0.003)$ for all treatments relative to their values on $11 \mathrm{Feb}$. 2015. Coumestrol was higher $(P=0.032)$ in the short rotation than medium and long rotation alfalfa plots with $25.6 \pm 6.3$ and $10.6 \pm 2.6 \mathrm{mg}$ $\mathrm{kg}^{-1} \mathrm{DM}$, respectively. Coumestrol continued to increase and reached a moderately high peak of $75.5 \pm 18.6 \mathrm{mg} \mathrm{kg}^{-1} \mathrm{DM}$ on 25 Mar. 2015 with no differences $(P=0.168)$ among cutting frequencies. On this date regrowth was 6 (Stage 2), 8 (Stages 5 to 6), and 14 (Stage 9) weeks old. Stemphylium and common leaf spot [Pseudopeziza medicaginis (Lib.) Sacc.] were the dominant fungal pathogens present.

Second coumestrol spike (14 Apr. to 25 May 2015). All plots were cut after sampling on $25 \mathrm{Mar}$. 2015. On 14 Apr. 2015, the coumestrol content in the 3 -wk-old regrowth (Stage 0 ) was lower 


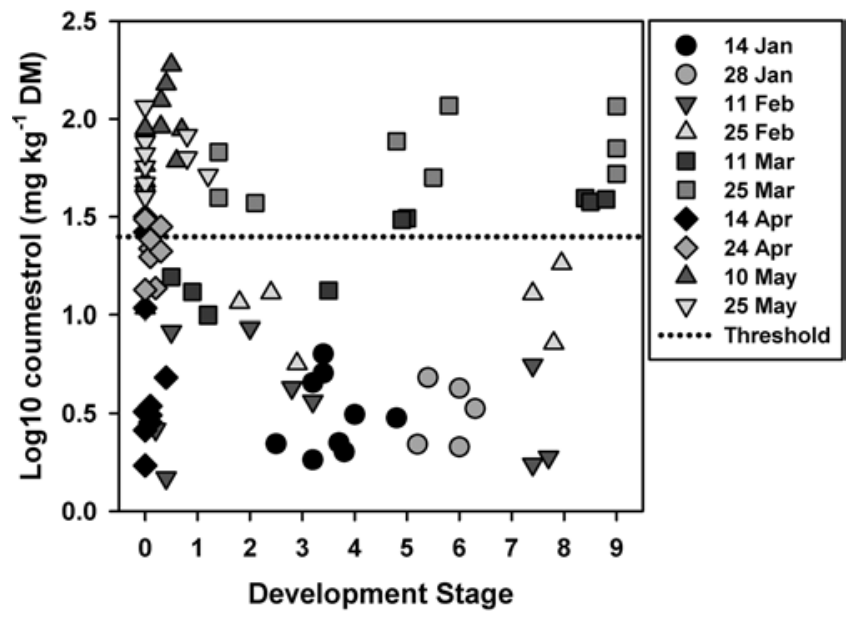

Fig. 3. Log $_{10}$ of coumestrol content $\left(\mathrm{mg} \mathrm{kg}^{-1} \mathrm{DM}\right)$ between 14 Jan. and 25 May 2015 against $(r=-0.134 ; P=0.218)$ development stage, where Stages 0 to 2 are vegetative, Stages 3 to 4 are bud, Stages 5 to 6 are flowering, and Stages 7 to 9 are seedpod (Table 5). Dotted horizontal line is the $\log _{10}$ of the critical value ( $25 \mathrm{mg} \mathrm{kg}^{-1} \mathrm{DM}$ ) above which alfalfa is reported to be a risk for ewe reproductive performance.

$(P<0.001)$ than on $25 \mathrm{Mar}$. in all plots. The short rotation plots had higher coumestrol than the medium and long rotations with $7.9 \pm 1.94$ vs. $3.3 \pm 0.80 \mathrm{mg} \mathrm{kg}^{-1} \mathrm{DM}$, respectively.

Coumestrol content increased $(P<0.001)$ in all plots on 10 May 2015 relative to the content on 14 and 24 Apr. 2015. On this date all alfalfa was vegetative (Stages 0 to 1 ). The short rotation alfalfa had 2 -wk regrowth $(3.7 \pm 0.67 \mathrm{~cm}$ tall), and the medium and long rotation alfalfa had 6-wk regrowth $(22 \pm 1.1 \mathrm{~cm})$. Short rotation plots had lower coumestrol content than the long rotation plots with $58.2 \pm 14.3$ and $120 \pm 29.6 \mathrm{mg} \mathrm{kg}^{-1} \mathrm{DM}$, respectively. Medium rotation plots had $100 \pm 24.6 \mathrm{mg} \mathrm{kg}^{-1} \mathrm{DM}$, which was not significantly different from the other cutting frequencies. On 25 May 2015, there was no change $(P=0.105)$ in coumestrol relative to 10 May 2015, including in the regrowth of the alfalfa cut at 6-wk regrowth on 10 May 2015. All alfalfa was vegetative (Stages 0 to 1 ) and regrowth ages of four (short rotation), two (medium rotation), and $8 \mathrm{wk}$ (long rotation) were present.

Coumestrol content vs. developmental stage. $\log _{10}$ transformed coumestrol content was not correlated $(r=-0.134$; $P=0.218$ ) with development stage (Fig. 3). In the late developmental stages, (i.e., from flowering [Stage 6] to mature seedpods [Stage 9]), both low (1-10 $\left.\mathrm{mg} \mathrm{kg}^{-1} \mathrm{DM}\right)$ and high (100-150 $\mathrm{mg} \mathrm{kg}^{-1} \mathrm{DM}$ ) coumestrol contents were measured. Likewise, at the early vegetative developmental stages (Stages 0 to 2), low to extreme (>150 mg kg-1 DM) coumestrol levels were measured. At the bud stages (Stages 3 to 4 ) only low coumestrol contents were measured, however no samples were at the bud stages on the dates when coumestrol content was high (25 Mar., 10 May, and 25 May 2015).

\section{Experiment 2: Cultivar}

In Experiment 2a coumestrol content was not affected $(P=0.072)$ by cultivar but was affected $(P<0.001)$ by time. Alfalfa contained higher levels of coumestrol in May than from January to March (Fig. 4). In the January to March regrowth period average coumestrol content $(n=15)$ increased

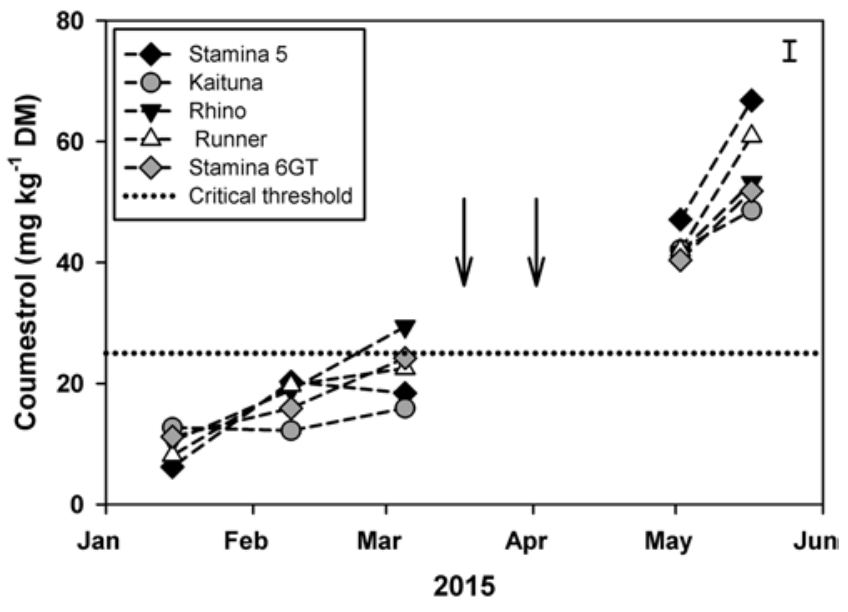

Fig. 4. Coumestrol content (mg kg-1 DM) of 'Stamina 5', 'Stamina 6GT', 'Grasslands Kaituna', 'Rhino', and 'Runner' over time in Field H7 of Ashley Dene Farm, Springston, Canterbury, New Zealand. Dashed lines are the $95 \%$ confidence interval. Error bar is the standard error of the mean for the effect of date. Dotted line is the level $\left(25 \mathrm{mg} \mathrm{kg}^{-1} \mathrm{DM}\right)$ above which alfalfa is reported to be a risk for ewe reproductive performance. The arrow symbols mark the onset and end of $2 \mathrm{wk}$ of ewe grazing to remove herbage.

$(P<0.001)$ from a low of $9.7 \pm 1.51 \mathrm{mg} \mathrm{kg}^{-1} \mathrm{DM}$ on 15 Jan. 2015 (Stage 0) to a moderately low $20.5 \pm 8.02 \mathrm{mg} \mathrm{kg}^{-1}$ DM on 5 Mar. 2015 (Stages 6-7). In the second regrowth period coumestrol increased from a moderate $42.7 \pm 3.31$ $\mathrm{mg} \mathrm{kg}^{-1}$ DM on 2 May 2015 (Stage 0 ) to a moderately high $56.2 \pm 3.24 \mathrm{mg} \mathrm{kg}^{-1}$ by 17 May 2015 (Stage 1 ).

For Experiment $2 \mathrm{~b} \log _{10}$ transformed coumestrol was affected by cultivar $(P<0.001)$ and date $(P<0.001)$. Overall mean coumestrol content was lowest $(P<0.05)$ in 'Force 4' and 'SFR27018' (Table 7). In addition, the coumestrol contents of '55Q27' and 'FD10' were lower $(P<0.05)$ than in 'Venus' and 'Takahe', while that of ' $54 \mathrm{~V} 09$ ' was also lower than for 'Takahe'. There was no difference $(P>0.05)$ in coumestrol content on 7 Mar. 2016 compared with 20 Apr. 2016. Mean coumestrol content across these dates was low, at $6.9 \pm 1.06 \mathrm{mg} \mathrm{kg}^{-1} \mathrm{DM}$. Coumestrol content was highest $(P<0.05)$ on 29 Mar. 2017, with a moderately high mean of $51.8 \pm 8.12 \mathrm{mg} \mathrm{kg}^{-1} \mathrm{DM}$. Coumestrol content was intermediate $(P<0.05)$ on 19 May 2017 , with a moderately low mean of $24.1 \pm 3.78 \mathrm{mg} \mathrm{kg}^{-1} \mathrm{DM}$. All cultivars exceeded the critical value of $25 \mathrm{mg} \mathrm{kg}^{-1} \mathrm{DM}$ reported to be a risk for ewe reproductive performance during this experiment.

\section{Fungal Pathogens}

The relationship between coumestrol content and fungal damage score was assessed for the field-grown alfalfa samples collected in Experiments 1 and 2, and the effect of the pathogen $S$. vesicarium on coumestrol content was assessed in inoculated alfalfa plants in Experiment 3.

\section{Field-Grown Alfalfa}

Coumestrol content of the field-grown alfalfa sampled in Experiments $1 \mathrm{a}, 1 \mathrm{~b}$, and $2 \mathrm{a}$ was exponentially related $[y=$ $\left.10^{(0.45+0.31 x)}, R^{2}=0.388\right]$ to the fungal damage score (Fig. 5). Of interest was a group of samples from Experiment la on 24 Mar. 2014 which had a fungal damage score of 4, but an average coumestrol content of $5.8 \pm 3.66 \mathrm{mg} \mathrm{kg}^{-1} \mathrm{DM}$. The 
Table 7. Mean coumestrol content of cultivars sampled in HRA9 from 7 Mar. 2016 to 19 May 2017.

\begin{tabular}{|c|c|c|}
\hline Cultivar & $\log _{10}$ coumestrol & Back-transformed coumestrol \\
\hline & $r$ & $\mathrm{ng} \mathrm{kg}^{-1} \mathrm{DM}$ \\
\hline Force 4 & 0.95 a & $9.0 \pm 1.17$ \\
\hline SFR27-0I8 & $0.97 \mathrm{a}$ & $9.3 \pm 1.22$ \\
\hline $55 Q 27$ & $\mathrm{I} .17 \mathrm{~b}$ & $14.9 \pm 1.94$ \\
\hline FDIO & $\mathrm{I} .18 \mathrm{~b}$ & $15.0 \pm 1.95$ \\
\hline 54V09 & $\mathrm{I} .20 \mathrm{~b}$ & $15.8 \pm 2.06$ \\
\hline Torlesse & $\mathrm{I} .24 \mathrm{bc}$ & $17.3 \pm 2.26$ \\
\hline Force 7 & $\mathrm{I} .26 \mathrm{bc}$ & $\mid 8.1 \pm 2.36$ \\
\hline Kaituna & 1.26 bc & $18.2 \pm 2.37$ \\
\hline Venus & $1.32 \mathrm{c}$ & $20.8 \pm 2.71$ \\
\hline Takahe & I.34 c & $22.1 \pm 2.88$ \\
\hline SEM & $\begin{array}{c}0.057 \\
* * *\end{array}$ & \\
\hline
\end{tabular}

*** Significant at the 0.001 probability level.

† Means followed by same lowercase letters were not significantly different $(\alpha=0.05)$.

fungal symptoms present on these plants were from a cool Stemphylium spp. biotype(s).

\section{Experiment 3: Inoculated Alfalfa}

$\log _{10}$ transformed coumestrol content of greenhouse-grown alfalfa was affected $(P<0.001)$ by infection with $S$. vesicarium. Infected alfalfa had a high coumestrol content of $131 \pm 33.6 \mathrm{mg}$ $\mathrm{kg}^{-1}$ DM. In contrast, the control had a low coumestrol content of $2.6 \pm 0.67 \mathrm{mg} \mathrm{kg}^{-1} \mathrm{DM}$. There was no effect of cultivar $(P=0.078)$ or duration between inoculation and sampling $(P=0.360) . S$. vesicarium infected plants had an average fungal damage score of $3.1 \pm 0.23(n=12)$ while control plants had an average score of $1.0 \pm 0.04(n=12)$. Coumestrol content was correlated $(r=0.890 ; P<0.001)$ with the fungal damage score.

Leaflets inoculated with $S$. vesicarium had a greater $(P<0.001)$ area of damage $(5.3 \pm 1.10 \%)$ than the control $(0.5$ $\pm 0.05 \%$ ) leaves. $\log _{10}$ transformed coumestrol content of leaves damaged with six needle punctures per leaflet prior to inoculation was affected by the interaction $(P=0.005)$ of cultivar and inoculation treatment. 'Stamina 5 ' leaves inoculated with $S$. vesicarium had the highest $(P<0.001)$ coumestrol content with an extreme level of $396 \pm 82.4 \mathrm{mg} \mathrm{kg}^{-1} \mathrm{DM}$ followed by inoculated 'Wairau' leaves with a high level of $143 \pm 35.6 \mathrm{mg}$ $\mathrm{kg}^{-1} \mathrm{DM}(n=6)$. In contrast, the control leaves had lower $(P<$ $0.001)$ coumestrol levels with a low mean of $2.5 \pm 0.40 \mathrm{mg} \mathrm{kg}^{-1}$ DM and no difference $(P=0.810)$ between the two cultivars. Coumestrol content was not affected $(P=0.685)$ by duration after inoculation (i.e., 1 vs. $2 \mathrm{wk}$ post-inoculation).

\section{Experiment 4: Aphids}

For Experiment 4a, there was an average of $4.6 \pm 0.76$ aphids per stem at harvest on the treated pots $(n=12)$. There was no difference $(P=0.214)$ in aphid numbers among the three cultivars. The mean alfalfa dry matter production was $9.0 \pm 0.24$ g per pot and all plants were vegetative (Stage 1 ). There was no difference in dry matter production among the cultivars $(P=0.095)$ or aphid treatments $(P=0.901)$. Overall, coumestrol levels were low but higher $(P<0.001)$ in aphid treated alfalfa $\left(5.3 \pm 0.42 \mathrm{mg} \mathrm{kg}^{-1} \mathrm{DM}\right)$ than in the control $\left(2.4 \pm 0.42 \mathrm{mg} \mathrm{kg}^{-1} \mathrm{DM}\right)$. There was no effect of cultivar

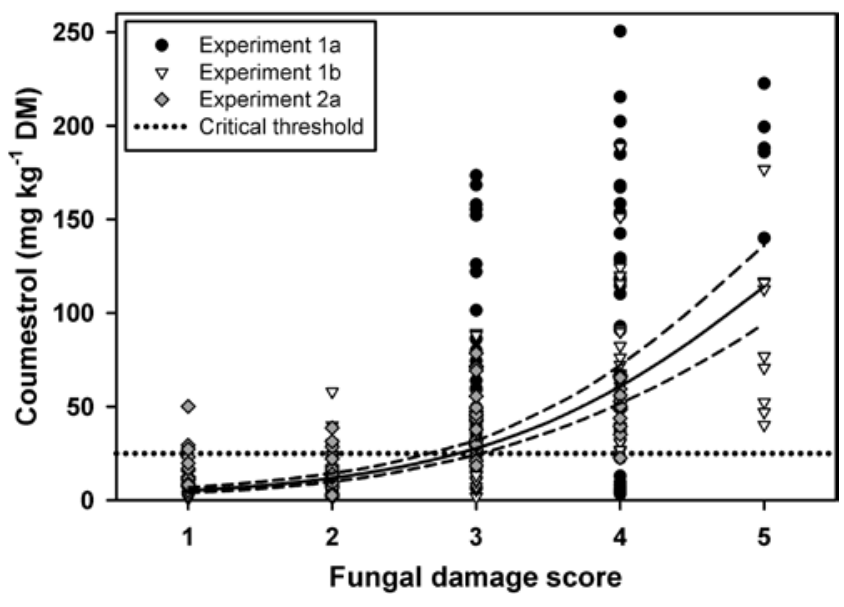

Fig. 5. Coumestrol content (mg kg-| DM) against fungal damage score in alfalfa sampled in Experiments $\mathrm{la}$, Ib, and 2a. The relationship $\left(P<0.001 ; R^{2}=0.388\right)$ is described by the equation: $y=10^{(0.45+0.31 x)}$. Dashed lines around the regression line are the $95 \%$ confidence interval. Dotted line is the critical level $(25$ $\mathrm{mg} \mathrm{kg}{ }^{-1}$ DM) above which alfalfa is reported to be a risk for ewe reproductive performance.

$(P=0.104)$ on the coumestrol content. In the aphid-treated alfalfa there was no relationship $(P=0.874)$ between the average number of aphids per stem and coumestrol content.

For Experiment $4 \mathrm{~b}$ alfalfa leaves that supported an aphid within a clip cage had a higher $(P=0.011) \log _{10}$ transformed coumestrol content than leaves without an aphid. Coumestrol content was negligible at $0.43 \pm 0.069 \mathrm{mg} \mathrm{kg}^{-1} \mathrm{DM}$ in aphidaffected leaves and $0.23 \pm 0.036 \mathrm{mg} \mathrm{kg}^{-1}$ in control leaves, and there was no effect $(P=0.191)$ of cultivar. Stained leaflets had no fungal damage, indicating no secondary infection around the sites of aphid damage.

\section{DISCUSSION}

\section{Fungal Pathogens}

Coumestrol content in alfalfa was predominantly elevated in response to fungal infection. Fungal pathogens, in particular Stemphylium leaf spot, common leaf spot, and spring black stem and leaf spot were present on field plants when spikes in coumestrol content occurred. In contrast, when pathogens were not present (damage score of 1 ) or only present at low levels (damage score of 2) the coumestrol levels were low. This was in line with previous studies in which coumestrol content tended to increase in response to fungal infection (Bickoff et al., 1967; Hanson et al., 1965; Loper and Hanson, 1964; Sherwood et al., 1970).

The level of fungal disease that can cause at-risk levels (for sheep) of coumestrol in alfalfa was problematic to quantify consistently. The fungal damage score uses the pathogen risk assessment key from James (1971) to estimate the extent of disease (Table 4). However, this damage score is subjective and can vary among observers. Overall, coumestrol contents measured in these field experiments did not strongly relate $\left(R^{2}=0.384\right)$ to fungal damage scores (Fig. 5). Based on the relationship between coumestrol content and fungal damage score, alfalfa with a damage score of 1 or 2 was generally expected to be safe for ewes grazing during the mating season. However, alfalfa with damage scores of 3 or more may or may not be safe as the variation around the mean was large. Results from this research highlighted the difficulty 
of predicting coumestrol content from visual scores, but also indicated disease-free alfalfa was safe to graze. A notable outlier was alfalfa sampled on 24 Mar. 2014 for Experiment 1a. This alfalfa was assigned a damage score of 4 due to Stemphylium leaf spot symptoms but had low coumestrol. A characteristic of the cool-type Stemphylium spp. infection is a sharp border between the necrotic lesion and the healthy leaf tissue. This may limit the coumestrol response in the healthy surrounding tissue. In contrast, alfalfa inoculated under controlled conditions with $S$. vesicarium did have elevated coumestrol levels. Further investigation is required to address this discrepancy between the field and greenhouse results. However, as $S$. vesicarium has been shown to increase coumestrol content, the safest option at this stage is for farmers to consider alfalfa infected with Stemphylium leaf spot, and all other fungal pathogens, to have heightened coumestrol levels.

Weekly application of fungicide has been shown to reduce the accumulation of coumestrol in alfalfa (Hanson et al., 1965; Purves et al., 1981). Future research could determine the effectiveness of less frequent applications with current fungicides on the market to provide a more economic option.

\section{Cultivar}

All of the cultivars in Experiments $2 \mathrm{a}$ and $2 \mathrm{~b}$ produced coumestrol contents over the $25 \mathrm{mg} \mathrm{kg}^{-1} \mathrm{DM}$ reported to affect ewe reproductive performance (Fields et al., in press; Ramòn et al., 1993; Smith et al., 1979). There were no differences among the five cultivars tested in Experiment 2a (Fig. 4). In contrast, for Experiment 2b, 'Force 4' and 'SFR27-018' had lower mean coumestrol contents than the eight other cultivars tested, which could be investigated in future studies. In Experiment 3 it was hypothesized that the modern 'Stamina 5' cultivar would produce less coumestrol than the older susceptible 'Wairau' cultivar in response to $S$. vesicarium. However this was not the case as infected leaves of 'Stamina 5' accumulated higher levels of coumestrol than 'Wairau'. The coumestrol response seen in the modern alfalfa cultivars was possibly because fungal diseases such as Stemphylium leaf spot, spring black stem and leaf spot, and common leaf spot do not appear to have been the focus of recent alfalfa breeding efforts. Typically, cultivar resistance information does not provide resistance levels to these pathogens and in cases where they do they fall under a general "leaf diseases" category (Lattimore, 2013). These findings indicate that breeding cultivars for fungal resistance to a wider range of pathogens may reduce the coumestrol response in alfalfa. This requires further research to prioritize those pathogens which cause the greatest accumulation of coumestrol and/or are most commonly present in alfalfa crops across growing environments. However, resistance breeding could be limited by the standard method used for determination of cultivar resistance in alfalfa, which is based on the percentage of greenhouse-grown seedlings that are resistant. Highly resistant cultivars have over $51 \%$ of plants resistant, while moderately resistant cultivars have 15 to $30 \%$ of plants resistant, and susceptible cultivars have 0 to $5 \%$ of plants resistant. This means that even in cultivars highly resistant to a particular pathogen, up to almost half of the plants could still be susceptible and thus have elevated coumestrol contents.

\section{Aphids}

Negligible increases in coumestrol content were observed with five aphids per stem (Experiment 4a) or a single aphid on a leaf for $5 \mathrm{~d}$ (Experiment $4 \mathrm{~b})$. The coumestrol levels were well below the $25 \mathrm{mg} \mathrm{kg}^{-1} \mathrm{DM}$ considered a risk to ewe reproduction and below those measured in the field grown alfalfa (Experiments 1 and 2). The coumestrol response observed here was unlikely to be due to a secondary infection by fungi at the site of aphid damage as no hyphae were detected in the stained leaves of Experiment $4 \mathrm{~b}$.

The response of coumestrol to aphids was in line with previous field and greenhouse studies that showed a response to aphid herbivory (Kain and Biggs, 1980; Loper, 1968). However, Kain and Biggs (1980) found that aphid numbers greater than 30 per stem could cause coumestrol to reach 40 to $90 \mathrm{mg} \mathrm{kg}^{-1} \mathrm{DM}$. Therefore, in cases where aphid numbers are high ( $>30$ per stem) farmers may consider removing ewes from alfalfa prior to mating, even in the absence of fungal disease. In Experiment $4 \mathrm{a}$ the aphids were at a rate of five aphids per stem, which was below production damaging levels, with no effect of treatment on dry matter per pot. However, $4 \mathrm{wk}$ of exposure to this low incidence of aphids did not cause coumestrol levels that would be of concern for sheep fecundity which is a promising indication that aphid herbivory alone is not as important a factor as previously indicated (Kain and Biggs, 1980).

\section{Development Stage}

Development stage of the alfalfa crop did not affect coumestrol content. This supports previous growth-chamber research which showed coumestrol levels in alfalfa were low across development stages (Loper and Hanson, 1964). However it contrasts with findings of previous field research which showed that heightened coumestrol content coincided with flowering and seed set stages (Bickoff et al., 1960; Hanson et al., 1965; Seguin et al., 2004). It seems likely that field research which follows stands through the growing season, but does not isolate the effect of regrowth age or developmental stage is confounded by other factors, particularly fungal infection.

In Experiment 1a, when young (Stage 0) and older (Stage 2) vegetative regrowth were simultaneously compared over time in the field, coumestrol content increased at the same time (Fig. 1). For example, between 7 and 21 Apr. 2014, coumestrol content increased from moderate to high in both 2 - and 6-wkold alfalfa regrowth. These crops remained vegetative due to alfalfa being a long day plant. This means that the thermal time requirements for flowering increase through the autumn period while the temperatures also decrease (Moot et al., 2003). Experiment $1 \mathrm{~b}$ showed that alfalfa at vegetative or flowering stages could contain either low or high levels of coumestrol. Vegetative alfalfa had increased coumestrol content at the same time as reproductive age alfalfa in stands on 25 Mar. 2015 (Fig. 3). There was no difference in the amount of coumestrol among plots of vegetative, flowering, and seedpod alfalfa with a moderately high coumestrol content of $76 \mathrm{mg} \mathrm{kg}^{-1} \mathrm{DM}$. This confirmed that the elevation in coumestrol content was independent of development stage or crop regrow th duration.

After high coumestrol plots were mown coumestrol contents were, in most cases, lower in the regrowth when sampled $2 \mathrm{wk}$ later. An exception was the 4-wk cutting interval in Experiment la which did not show this response. After cutting of alfalfa that 
had moderately high coumestrol on 5 May 2014 the coumestrol increased to a high level in the 2 -wk-old regrowth on 19 May 2014. The 2 -wk cutting regime also did not show a decline in coumestrol content after cutting and had a similar, albeit lower, coumestrol pattern to the unmown alfalfa. These inconsistencies in the more frequently cut plots may have been due to the low quantity and height of the regrowth between cuts (i.e., less than the mower height of $65 \mathrm{~mm}$ ). This would have resulted in the mower leaving behind leafy residual material which was then followed by further low growth due to fall dormancy. This may have resulted in a large proportion of leaf material from previous re-growths being harvested with the younger regrowth material from which it could not be differentiated. Future studies should use grazing ewes to ensure all leafy material is removed.

Based on this experiment, farmers can graze mating sheep on alfalfa that is flowering without encountering effects on ewe fecundity. This is important as late summer to early fall is the beginning of the mating season of sheep and also a time when farmers are recommended to avoid harvesting alfalfa until flowering to build root reserves to improve stand persistence (Moot et al., 2003). However, it is important to note that older alfalfa crops are more likely to have experienced the conditions suitable for fungal infection and once coumestrol is in the plant it remains there until the herbage is removed.

These experiments did not test for other coumestans that are likely to be present in alfalfa such as $4^{\prime}$-methoxycoumestrol, 3 '-methoxycoumestrol, and wairol. Future research to determine their effects on ewe reproductive performance and the factors that they are produced in response to would be of benefit. In addition, the focus of these studies was to provide advice for sheep production systems. Further research to determine the response of cattle reproductive performance to coumestrol would be of benefit, both to corroborate with the studies described in Reed (2016), and to provide an indication of the coumestrol level that may be a risk to cattle fertility. Across the experiments in this study a range of alfalfa stand ages were used, however this was often in different months or years and so they cannot be compared. A direct comparison would be useful to determine whether the age of the stand affects the likelihood of coumestrol being elevated, for example due to increased disease susceptibility in old alfalfa stands. It would also be beneficial to look at crop rotation length to determine whether a suitable break length could be used to reduce the risk of disease presence and therefore coumestrol accumulation.

Further research could also focus on the environmental conditions that are present when elevations in coumestrol contents occur. The simultaneous increases in coumestrol content observed across all plots, regardless of regrowth age, indicates that fungal infection may occur in response to the weather. A model predicting coumestrol content based on meteorological conditions would allow farmers to be provided with advice on a regional basis and could overcome the limitations of using a subjective fungal damage score.

\section{CONCLUSIONS}

The aim of this study was to isolate a range of agronomic factors to assess their individual effects on coumestrol content of alfalfa to enable decisions to be made on whether or not to graze alfalfa with ewes during the period leading up to and during the mating period.

1. Fungal infected alfalfa samples had higher coumestrol content than uninfected samples. When alfalfa was inoculated with stemphylium the coumestrol content was significantly elevated. This effect of fungal infection confirms findings of previous research.

2. The fungal damage score was a poor predictor of coumestrol content.

3. Aphids, at below production damaging levels, had a negligible effect on coumestrol content.

4. Development stage did not affect coumestrol content and therefore alfalfa which is vegetative or flowering but is not infected by fungi is not expected to have elevated coumestrol content.

5. Cultivars currently on the market in New Zealand produced at-risk levels of coumestrol and therefore research focused on which fungal pathogens are currently having the greatest impact and breeding focused on fungal resistance is recommended. It may also be useful to assess whether the $51 \%$ threshold for a highly resistant rating is sufficient to limit coumestrol accumulation.

\section{ACKNOWLEDGMENTS}

Support and funding for this research was provided by Beef + Lamb NZ, Struthers Trust, Mr. Roland Stead, and Lincoln University APC Committee. We thank Martin Wellby, Dr. Richard Sedcole, Dr. Hayley Ridgway, and Lincoln University Nursery and Field Research Centre staff for their technical contributions to this research. We are grateful to the anonymous reviewers whose thorough comments helped to improve the manuscript.

\section{REFERENCES}

Batterham, T.J., N.K. Hart, J.A. Lamberton, and A.W.H. Braden. 1965. Metabolism of oestrogenic isoflavones in sheep. Nature 206:509. doi:10.1038/206509a0

Bickoff, E.M., A.N. Booth, A.L. Livingston, and A.P. Hendrickson. 1960. Observations on the effect of drying on estrogenic activity of alfalfa samples of varying maturity. J. Anim. Sci. 19:745-753. doi:10.2527/ jas1960.193745x

Bickoff, E.M., G.M. Loper, C.H. Hanson, J.H. Graham, S.C. Witt, and R.R. Spencer. 1967. Effect of common leafspot on coumestans and flavones in alfalfa. Crop Sci. 7:259-261. doi:10.2135/cropsci1967.0 011183X000700030027x

Brown, H.E., D.J. Moot, and K.M. Pollock. 2005. Herbage production, persistence, nutritive characteristics and water use of perennial forages grown over 6 years on a Wakanui silt loam. N. Z. J. Agric. Res. 48:423-439. doi:10.1080/00288233.2005.9513677

Coop, I.E. 1977. Depression of lambing percentage from mating on lucerne. Proc. N.Z. Soc. Anim. Prod. 37:149-151.

Cox, J.E. 1978. Soils and agriculture of Part Paparua County, Canterbury, New Zealand. New Zealand Soil Bureau, Wellington.

Cox, R.I., and A.W.H. Braden. 1974. The metabolism and physiological effects of phyto-oestrogens in livestock. Proceedings of the Australian Society of Animal Production 10:122-129. Australian Society of Animal Production, Wagga Wagga, NSW, Australia.

Dunbier, M., and H. Easton. 1982. Cultivar development. In: R.B. WynnWilliams, editor, Lucerne for the 80's. Agron. Soc. New Zealand, Christchurch, New Zealand. p. 117-120. 
Farrell, J.A., and M.W. Stufkens. 1981. Field evaluation of lucerne cultivars for resistance to blue-green lucerne aphid and pea aphid (Acyrthosiphon spp.) in New Zealand. N.Z. J. Agric. Res. 24:217-220. doi:10.1 080/00288233.1981.10420892

Fick, G.W., and S.C. Mueller. 1989. Alfalfa: Quality, maturity, and mean stage of development. Cornell Cooperative Extension, Ithaca, NY.

Fields, R.L., D.J. Moot, and G.K. Barrell. 2017. Coumestrol content of lucerne under drought stress, Proceedings of the 18th Australian Society of Agronomy Conference, Ballarat, Australia.

Fields, R.L., D.J. Moot, J.R. Sedcole, and G.K. Barrell. Recovery of ovulation rate in ewes following their removal from an oestrogenic lucerne forage. Anim. Prod. Sci. . doi:10.1071/AN17586

Galey, F.D., L.E. Mendez, W.E. Whitehead, D.M. Holstege, K.H. Plumlee, and B. Johnson. 1993. Estrogenic activity in forages: Diagnostic use of the classical mouse uterine bioassay. J. Vet. Diagn. Invest. 5:603-608. doi:10.1177/104063879300500416

Glass, N.L., and G.C. Donaldson. 1995. Development of primer sets designed for use with the PCR to amplify conserved genes from filamentous ascomycetes. Appl. Environ. Microbiol. 61:1323-1330.

Hanson, C.H., G.M. Loper, G.O. Kohler, E.M. Bickoff, K.W. Taylor, W.R. Kehr, E.H. Stanford, J.W. Dudley, M.W. Pedersen, E.L. Sorenson, H.L. Carnahan, and C.P. Wilsie. 1965. Variation in coumestrol content of alfalfa as related to location, variety, cutting, year, stage of growth, and disease. Tech. Bull. USDA No. 1333:1-43.

Harvey, I.C., and R.J. Martin. 1980. Leaf spot diseases on lucerne cultivars. N. Z. J. Exp. Agric. 8:295-296. doi:10.1080/03015521.1980.1 0426276

Hawthorne, B. 1983. Variation in pathogenicity among isolates of Verticillium albo-atrum from lucerne. N. Z. J. Agric. Res. 26:405-408. doi:10.1080/00288233.1983.10427051

Hewitt, A.E. 2010. New Zealand soil classification. 3rd ed. Manaaki Whenua Press, Lincoln, New Zealand.

Irwin, J., and R. Bray. 1991. Variation in virulence within the cool temperature biotype of Stemphylium vesicarium (Wallr.) Simmons, a lucerne leaf spot pathogen. Aust. J. Exp. Agric. 31:793-795. doi:10.1071/ EA9910793

James, W.C. 1971. An illustrated series of assessment keys for plant diseases, their preparation and usage. Can. Plant Dis. Surv. 51:39-65.

Kain, W.M., and D.R. Biggs. 1980. Effect of pea aphid and bluegreen lucerne aphid (Acyrthosiphon spp.) on coumestrol levels in herbage of lucerne (Medicago sativa). N. Z. J. Agric. Res. 23:563-568. doi:10.10 80/00288233.1980.10417883

Kempthorne, O., and L. Folks. 1971. Probability, statistics, and data analysis. Iowa State Univ. Press, Ames, IA.

King, B.J., S.M. Robertson, J.F. Wilkins, and M.A. Friend. 2010. Shortterm grazing of lucerne and chicory increases ovulation rate in synchronised Merino ewes. Anim. Reprod. Sci. 121:242-248. doi:10.1016/j.anireprosci.2010.06.007

Lattimore M.-A. 2013. Lucerne varieties. Primefact 1306. New South Wales Dep. of Primary Industries, New South Wales Government.

Loper, G.M. 1968. Effect of aphid infestation on the coumestrol content of alfalfa varieties differing in aphid resistance. Crop Sci. 8:104-106. doi:10.2135/cropsci1968.0011183X000800010031x

Loper, G.M., and C.H. Hanson. 1964. Influence of controlled environmental factors and two foliar pathogens on coumestrol in alfalfa. Crop Sci. 4:480-482. doi:10.2135/cropsci1964.0011183X000400 050013x

Moot, D.J., H.E. Brown, E.I. Teixeira, and K.M. Pollock. 2003. Crop growth and development affect seasonal priorities for lucerne management. In: D.J. Moot, editor, Legumes for dryland pastures. N.Z. Grassl. Assoc., Research and Practice Series 11. New Zealand Grassland Association, Dunedin. p. 201-208.

Moravcová, J., T. Kleinová, R. Loučka, I. Tyrolová, F. Kvasnička, M. Dušek, M. Čeřovský, and P. Matucha. 2004. Coumestrol content of alfalfa following ensilage. Anim. Feed Sci. Technol. 115:159-167. doi:10.1016/j.anifeedsci.2004.01.005
Noble, M.D. 1958. A simplified clip cage for aphid investigations. Can. Entomol. 90:760. doi:10.4039/Ent90760-12

O'Donnell, K., and E. Cigelnik. 1997. Two divergent intragenomic rDNA ITS2 types within a monophyletic lineage of the fungus Fusarium are nonorthologous. Mol. Phylogenet. Evol. 7:103-116. doi:10.1006/ mpev.1996.0376

Pethybridge, S.J., and S.C. Nelson. 2015. Leaf Doctor: A new portable application for quantifying plant disease severity. Plant Dis. 99:1310-1316. doi:10.1094/PDIS-03-15-0319-RE

Purves, R.G., N.D. Hood, and M.W. Dunbier. 1981. The effect of cutting management and fungicide application on coumestrol levels in three lucerne cultivars. Proc. N.Z. Weed Pest Control Conf. 34:25-28.

Ramòn, J.P., J. Valderràbano, and J. Folch. 1993. Reproductive performance of Rasa Aragonesa ewes mated on lucerne (Medicago sativa 'Aragon') pastures. Small Rumin. Res. 11:323-329. doi:10.1016/0921-4488(93)90003-Z

Rattray, P.V., K.T. Jagusch, J.F. Smith, G. Winn, and K. MacLean. 1980. Getting an extra 20\% lambing from flushing ewes. In: Proceedings of the Ruakura Farmers' Conference. Ministry of Agriculture and Fisheries, New Zealand. p. 105-118.

Reed, K. 2016. Fertility of herbivores consuming phytoestrogen-containing Medicago and Trifolium species. Agriculture 6:35. doi:10.3390/ agriculture6030035

Saba, N., H.M. Drane, C.N. Hebert, J.E. Newton, and J.E. Betts. 1972. Effect of disease on the oestrogenic activity and coumestrol content of white clover and lucerne. J. Agric. Sci. 78:471-475. doi:10.1017/ S002185960002640X

Scales, G.H., R.A. Moss, and R.W. Kelly. 1977. Reproductive performance of ewes mated on lucerne. Proc. N.Z. Soc. Anim. Prod. 37:152-157.

Seguin, P., W. Zheng, and A. Souleimanov. 2004. Alfalfa phytoestrogen content: Impact of plant maturity and herbage components. J. Agron. Crop Sci. 190:211-217. doi:10.1111/j.1439-037X.2004.00100.x

Sherwood, R.T., A.F. Olah, W.H. Oleson, and E.E. Jones. 1970. Effect of disease and injury on accumulation of a flavonoid estrogen, coumestrol, in alfalfa. Phytopathology 60:684-688. doi:10.1094/ Phyto-60-684

Smith, J.F., K.T. Jagusch, L.F.C. Brunswick, and R.W. Kelly. 1979. Coumestans in lucerne and ovulation in ewes. N. Z. J. Agric. Res. 22:411-416. doi:10.1080/00288233.1979.10430768

Thompson, K.F., J.R. Sedcole, D. O’Connell, K.G. Geenty, and A.R. Sykes. 1990. Spring and summer pasture feeding and ewe reproduction and wool growth. Proc. of the N.Z. Grassl. Assoc. 52:123-127.

Tuite, J. 1969. Plant pathological methods: Fungi and bacteria. Burgess Publ. Co., Minneapolis, MN.

USDA. 1999. Soil taxonomy: A basic system of soil classification for making and interpreting soil surveys. 2nd ed. USDA-NRCS, Washington, DC.

Vincent, J.M. 1970. A manual for the practical study of the root-nodule bacteria. Blackwell Sci. Publ., Oxford and Edinburgh, United Kingdon.

Wang, G., S.S. Kuan, O.J. Francis, G. Ware, and A.S. Carman. 1990. A simplified HPLC method for the determination of phytoestrogens in soybean and its processed products. J. Agric. Food Chem. 38:185190. doi:10.1021/jf00091a041

Webb, T.H., and C.M. Bennett. 1986. Soils of Ashley Dene. Report CH17. Dep. of Scientific and Industrial Research Soil Bureau, New Zealand.

White, T.J., T. Bruns, S. Lee, and J. Taylor. 1990. Amplification and direct sequencing of fungal ribosomal RNA genes for phylogenetics. In: M.A. Innis, et al., editors, PCR protocols: A guide to methods and applications. Academic Press Inc, New York. p. 315-322. doi:10.1016/B978-0-12-372180-8.50042-1 